\title{
GMR
}

\section{Mixed models for selection of Jatropha progenies with high adaptability and yield stability in Brazilian regions}

\author{
P.E. Teodoro ${ }^{1}$, L.L. Bhering ${ }^{1}$, R.D. Costa ${ }^{2}$, R.B. Rocha ${ }^{3}$ and B.G. Laviola ${ }^{2}$ \\ ${ }^{1}$ Departamento de Biologia Geral, Universidade Federal de Viçosa, \\ Viçosa, MG, Brasil \\ ${ }^{2}$ Embrapa Agroenergia, Brasília, DF, Brasil \\ ${ }^{3}$ Embrapa Rondônia, Porto Velho, RO, Brasil \\ Corresponding author: P.E. Teodoro \\ E-mail: eduteodoro@hotmail.com \\ Genet. Mol. Res. 15 (3): gmr.15038824 \\ Received May 19, 2016 \\ Accepted June 22, 2016 \\ Published August 18, 2016 \\ DOI http://dx.doi.org/10.4238/gmr.15038824
}

Copyright (C) 2016 The Authors. This is an open-access article distributed under the terms of the Creative Commons Attribution ShareAlike (CC BY-SA) 4.0 License.

\begin{abstract}
The aim of this study was to estimate genetic parameters via mixed models and simultaneously to select Jatropha progenies grown in three regions of Brazil that meet high adaptability and stability. From a previous phenotypic selection, three progeny tests were installed in 2008 in the municipalities of Planaltina-DF (Midwest), Nova PorteirinhaMG (Southeast), and Pelotas-RS (South). We evaluated 18 families of half-sib in a randomized block design with three replications. Genetic parameters were estimated using restricted maximum likelihood/best linear unbiased prediction. Selection was based on the harmonic mean of the relative performance of genetic values method in three strategies considering: 1) performance in each environment (with interaction effect); 2) performance in each environment (with interaction effect); and 3) simultaneous selection for grain yield, stability and adaptability.
\end{abstract}


Accuracy obtained (91\%) reveals excellent experimental quality and consequently safety and credibility in the selection of superior progenies for grain yield. The gain with the selection of the best five progenies was more than $20 \%$, regardless of the selection strategy. Thus, based on the three selection strategies used in this study, the progenies 4,11 , and 3 (selected in all environments and the mean environment and by adaptability and phenotypic stability methods) are the most suitable for growing in the three regions evaluated.

Key words: REML/BLUP; Genetic parameters; Genetic gain

\section{INTRODUCTION}

The worldwide demand for clean, renewable, and sustainable fuels to replace or supplement fossil fuels has made biofuels a great alternative (Freitas et al., 2016). Currently, there are different types of biofuels, especially biodiesel, which can be obtained from any vegetable oil and whose production has strong social, economic, and environmental advantages (Freitas et al., 2011; Santos et al., 2016). Jatropha (Jatropha curcas L.) is a perennial crop with the potential for high quality oil production for producing biodiesel. Despite having wide adaptability to diverse environments in Brazil, the species is in the domestication phase, and no cultivars and cropping system have yet been validated for the different producing regions in the country (Dias et al., 2012). Thus, the selection of high adaptability and stability genotypes is needed so that this oleaginous crop can be established as an alternative for biodiesel production (Laviola et al., 2014).

Progeny tests are a type of genetic design that are most used in plant species breeding programs because they allow for the estimation of the additive variance of traits with complex inheritance, governed by several genes of small effect. In developing a new variety of Jatropha, the performance of the best progenies in different environments should be considered (Bhering et al., 2013). Differential response of plants or genotypes to environmental changes is of great importance for different crop breeding programs, since the genotype $\mathrm{X}$ environment (G X E) interaction limits selection gains that are necessary to estimate the magnitude and nature of this interaction. These estimates enable the actual impact of selection to be assessed and ensure high reliability in genotype recommendations for a given location or environment groups (Rosado et al., 2012).

However, despite its importance, a simple analysis of the G X E interaction does not provide complete and accurate information about the behavior of each genotype in various environmental conditions. It is necessary to perform adaptability and phenotypic stability analysis, identifying genotypes with predictable behavior, which are responsive to environmental variations in specific or broad conditions (Cruz et al., 2012). Thus, selection methods that incorporate stability and adaptability in a single statistic can be considered superior compared to those that use only the yield as selection criteria (Resende, 2007).

The use of mixed models for analyzing the stability and adaptability of genotypes was proposed for perennial crops such as pine (Resende et al., 1996), and its application has been widespread in the analysis of several crops, both perennials and annuals. A restricted maximum likelihood (REML) procedure estimates variance components necessary for the model, while the best linear unbiased prediction (BLUP) estimates the genotypic value (Resende, 2007),

Genetics and Molecular Research 15 (3): gmr.15038824 
producing three statistics: harmonic mean of genetic values (HMGV), relative performance of genetic values (RPGV), and harmonic mean of the relative performance of predicted genetic values (HMRPGV).

This methodology allows correlated errors within sites to be considered, as well as the stability and adaptability in the selection of superior genotypes; it provides genetic values accounting for experimental error; and it can be applied to any number of environments. In addition, this method, unlike other methods, generates results in the unit itself or the scale of the assessed trait, which can be interpreted directly as genetic values. This model also allows additional inferences to be made, such as the following: selecting specific genotypes for each location; selecting stable genotypes across locations; selecting genotypes responsive (with high adaptability) to improvement of the environment; and selecting by the three attributes (yield, stability, and adaptability) simultaneously (Rosado et al., 2012).

HMGV, RPGV, and HMRPGV statistics predicted by BLUP have been used as measures for the interpretation of genotypic stability and adaptability of crops such as common bean (Carbonell et al., 2007), sugarcane (Bastos et al., 2007), cashew trees (Maia et al., 2009), eucalyptus (Rosado et al., 2012), rice (Neto et al., 2013), and cowpea (Torres et al., 2016). Thus, the aim of this study was to select, via mixed models, Jatropha progenies with high adaptability and stability that can be grown in three Brazilian regions.

\section{MATERIAL AND METHODS}

Progeny tests were installed in the Midwest, Southeast, and South of Brazil in February 2008 in the following municipalities: Planaltina-DF (Midwest), Nova PorteirinhaMG (Southeast), and Pelotas-RS (South). We evaluated 18 half-sib progenies $(1,2, \ldots, 18)$ in a randomized block design with three replications and five plants, arranged in line per useful plot. The genealogy of the progenies is detailed in Laviola et al. (2014). Seedlings cultivated for about 60 days with $4 \times 2 \mathrm{~m}$ spacing were used in the tests. Management practices were based on Dias et al. (2007), with adaptations based on management of Jatropha in Brazil and worldwide (Bahadur et al., 2013; Carels et al., 2013; Resende et al., 2013).

We assessed the grain yield (11-12\% moisture) in the agricultural year 2012/2013, corresponding to the third year of production of Jatropha. In the plots, the grain yield (kg/plot) was assessed and later converted into grain yield ( $\mathrm{kg} / \mathrm{ha})$. Two to four harvests of mature fruits were performed owing to uniform ripening of the fruit in each evaluation region.

For assessing the G X E interaction effect and estimating genetic parameters, we used the statistical model predicted by Equation 1:

$$
\mathrm{y}=\mathrm{Xb}+\mathrm{Zg}+\mathrm{Wc}+\mathrm{e}
$$

where $\mathrm{y}, \mathrm{b}, \mathrm{g}, \mathrm{c}$, and e correspond to the fixed effects of data vectors (blocks means across environments), genotype effects (random), genotype $X$ environment effect (random), and random errors, respectively; $\mathrm{X}, \mathrm{Z}$, and $\mathrm{W}=$ incidence matrices for $\mathrm{b}, \mathrm{g}$, and $\mathrm{c}$, respectively.

Through this model, empirical BLUP predictors of genotypic values without interaction, given by $\hat{\mu}+\hat{g}_{i}$, where $\hat{\mu}$ is the mean of all environments and $\hat{\mathrm{g}}_{\mathrm{i}}$ is the genotypic effect without G X E interaction, were obtained. Selection was based in three selection strategies based on predicted genetic values considering 1) performance in each environment (with interaction effect); 2) mean performance of progenies in all environments (without interaction effect); and 3) simultaneous selection for grain yield, stability, and adaptability.

Genetics and Molecular Research 15 (3): gmr.15038824 
For the first strategy, the genotypic values $(\mathrm{Vg})$ were predicted by Equation 2:

$$
V g=\hat{\mu}_{j}+\hat{g}_{i}+(\hat{g} e)_{i j}
$$

where $\hat{\mu}_{\mathrm{j}}$ is the mean of environment $\mathrm{j}, \hat{\mathrm{g}}_{\mathrm{i}}$ is the genotypic effect of the genotype $\mathrm{i}$ in the environment $\mathrm{j}$, and $(\hat{\mathrm{ge}})_{\mathrm{ij}}$ is the G X E interaction effect relative to genotype $\mathrm{i}$. The gain with selection of the best progenies, according to strategy 1, was predicted by Equation 3:

$$
\mathrm{GS}(\%)=\left[\left(\frac{V g_{s j}-V g_{j}}{V g_{j}}\right) \hat{h}_{m g}^{2}\right] 100
$$

where $\operatorname{Vg}_{\mathrm{sj}}$ is the mean genotypic value of the five progenies selected in the environment $\mathrm{j}, \mathrm{Vg}_{\mathrm{j}}$ is the mean genotypic value of all progenies in the environment $\mathrm{j}$, and $\hat{\mathrm{h}}_{\mathrm{mg}}^{2}$ is the heritability mean of the progeny.

For the second strategy, the prediction of $\mathrm{Vg}$ capitalizing the average interaction in different environments $\left(\hat{\mathrm{ge}}_{\mathrm{m}}\right)$ was given by Equation 4:

$$
\mathrm{Vg}=\hat{\mu}_{\mathrm{j}}+\hat{\mathrm{g}}_{\mathrm{i}}+\hat{\mathrm{ge}}_{\mathrm{m}}
$$

The gain with selection of the best progenies according to strategy 2 was predicted by Equation 5:

$$
\mathrm{GS}(\%)=\left[\left(\frac{\mathrm{Vg}_{\mathrm{s}}-\mathrm{Vg}}{\mathrm{Vg}}\right) \hat{\mathrm{h}}_{\mathrm{mg}}^{2}\right] 100
$$

where $\mathrm{Vg}_{\mathrm{s}}$ is the mean genotypic value of the five selected progenies in the mean environment, capitalizing on average interaction in different environments, $\mathrm{Vg}$ is the mean genotypic value of all progenies in the mean environment, and $\hat{\mathrm{h}}_{\mathrm{mg}}^{2}$ is the heritability mean of the progeny.

The values of the HMGVs for assessing the stability were obtained by Equation 6:

$$
\mathrm{HMGV}_{\mathrm{i}}=\frac{\mathrm{n}}{\sum_{\mathrm{j}=1}^{\mathrm{n}} \frac{1}{\mathrm{Vg}_{\mathrm{ij}}}}
$$

where $\mathrm{n}$ is the number of environments $(\mathrm{N}=3)$ were the genotype $\mathrm{i}$ was evaluated and $\mathrm{Vg}_{\mathrm{ij}}$ is the genotypic value of the genotype $i$ in the environment $j$, expressed as a proportion of the mean in this environment. The values of the RPGVs for adaptability were obtained using Equation 7:

Genetics and Molecular Research 15 (3): gmr.15038824 


$$
\operatorname{RPGV}_{i}=\frac{\sum_{j=1}^{n} V_{i j}}{n M_{j}}
$$

where $\mathrm{M}_{\mathrm{j}}$ is the mean of the grain yield in the environment $\mathrm{j}$. Joint selection, considering grain yield, stability, and adaptability simultaneously, is given by harmonic mean of the HMRPGVs is expressed in Equation 8:

$$
\operatorname{HMRPGV}_{i}=\frac{\mathrm{n}}{\sum_{\mathrm{j}=1}^{\mathrm{n}} \frac{1}{\mathrm{Vg}_{\mathrm{ij}}}}
$$

Thus, genotypes with higher HMRPGV are those that have simultaneously higher grain yield, adaptability, and genotypic stability to environments evaluated in this study.

The gain with selection of the best progenies according to each strategy was predicted by Equation 9:

$$
\mathrm{GS}(\%)=\left[\left(\frac{\mathrm{HMRPGVs}-\mathrm{HMRPGV}}{\mathrm{HMRPGV}}\right) \hat{\mathrm{h}}_{\mathrm{mg}}^{2}\right] 100 \quad \text { (Equation 9) }
$$

where HMRPGV is the mean of the harmonic mean of the relative performance of predicted genetic values from the five selected progenies, HMRPGV is the mean of the harmonic mean of the relative performance of predicted genetic values of all progenies, and $\hat{h}_{\mathrm{mg}}^{2}$ is the heritability mean of the progeny.

\section{RESULTS AND DISCUSSION}

The coefficient of variation was $23.39 \%$ (Table 1 ), which is was similar to other studies conducted with Jatropha (Laviola et al., 2012; Wani et al., 2012; Brasileiro et al., 2013; Everson et al., 2013; Laviola et al., 2014; Teodoro et al., 2016a,b). Since this is a quantitative trait with continuous distribution and complex inheritance influenced by the soil and climatic features of each environment, this value can be considered low, indicating good experimental precision. In another interpretation, higher values of the coefficient of genetic variation indicate that a substantial fraction of the genotypic variance was extracted from individual phenotypic variance. The accuracy in the selection of progenies obtained (91\%) confirmed high experimental precision according to the rating of Resende and Duarte (2007). Therefore, there is security and credibility in the selection and recommendation of Jatropha progenies investigated in this study.

According to Resende (2007), the heritability mean of progeny is estimated when using means of blocks as evaluation and/or selection criteria. Thus, the value obtained $(0.83)$ for this parameter indicates reliability in the selection of Jatropha progenies based on predicted genotypic values. The genotypic variance showed a higher magnitude compared to the variance of G X E interaction, which demonstrates predominance of genetic effects 
Table 1. Estimates of variance components for grain yield of 18 half-sib progenies of Jatropha evaluated in three regions in Brazil.

\begin{tabular}{l|c}
\hline Parameter & Estimate \\
\hline Genotypic variance & $115,340.48$ \\
\hline Variance of genotype X environment (G X E) interaction & $33,629.48$ \\
\hline Residual variance among plots & $115,874.90$ \\
\hline Individual phenotypic variance & $264,844.86$ \\
\hline Individual heritability coefficient in the broad sense & 0.44 \\
\hline Heritability mean of progeny & 0.83 \\
\hline Accuracy in the selection of progenies & 0.91 \\
\hline Coefficient of determination of the effects of G X E interaction & 0.13 \\
\hline Genotypic correlation across environments & 0.77 \\
\hline Coefficient of variation genetic (\%) & 23.33 \\
\hline Coefficient of variation experimental (\%) & 23.39 \\
\hline Overall mean (kg/ha) & $1,455.62$ \\
\hline
\end{tabular}

on growth performance of the progenies. This caused high values for coefficient of variation genetic, equivalent to $23.33 \%$ in relation to the overall mean, and $44 \%$ of the total phenotypic variability, represented by heritability mean of progeny. Results in similar magnitude were observed by Maia et al. (2009), Rosado et al. (2012), and Laviola et al. (2012), who estimated genetic parameters via REML/BLUP of cashew, eucalyptus, and Jatropha clones, respectively.

The variance of G X E interaction can inflate the phenotypic expression of a trait, especially those polygenic as grain yield, controlled by many small effect genes on the phenotype. This parameter quantifies the fraction of the total variation due to G X E interaction. Estimates of variance of genotype $\mathrm{X}$ environment interaction can be considered low, corresponding to $12.70 \%$ of the total phenotypic variation, favoring high genotypic correlation (genotypic correlation across environments equal to 0.77 ) among the environments.

Phenotypic value corresponds to the values obtained in the field evaluations, which are influenced by genotypic effect, effect of environment and of G x E interaction. In this last, the sum of genotypic variance, of the residual variance between plots and variance of G X E interaction results in individual phenotypic variance. Residual dispersion between plots represented $43.75 \%$ of this value, indicating that significant genetic progress has been achieved. Results in magnitudes higher than reported in this study were observed by Maia et al. (2009), Rosado et al. (2012), who used mixed models to evaluate the G X E interaction effects on cashew and eucalyptus clones, and observed that the residual variance between plots representing 66.51 and $65.04 \%$ respectively of individual phenotypic variance.

The genotypic correlation across environments indicates the reliability of the order of the best progenies in the tested environments. Generally, small changes were observed in the ordering of genotypes, because of the median magnitude of genotypic correlation across environments $(0.77)$ and higher accuracy in the selection of progenies (0.91). This indicates the occurrence of simple fraction of G X E interaction, favoring the selection of broader adaptation progenies. However, it can be verified in Table 2 that there were changes among the five best selected progenies in each environment and in the mean environment (capitalizing the mean interaction in different environments). This indicates that, despite the high magnitude of the genotypic correlation across environments and low variance of $\mathrm{G} x \mathrm{E}$ interaction, recommendations based on the mean of environments would not be the best strategy. By analyzing progeny 10, although among the five best in the environment mean, it had a performance lower than that of other progenies in Planaltina-DF and Nova Porteirinha-MG.

Genetics and Molecular Research 15 (3): gmr.15038824 
Table 2. Estimates of genotypic values of grain yield ( $\mathrm{kg} / \mathrm{ha}$ ) of 18 half-sib progenies of Jatropha evaluated in three environments in Brazil and for the mean environment (capitalizing the mean interaction in different environments).

\begin{tabular}{|c|c|c|c|c|}
\hline \multirow[t]{2}{*}{ Progeny } & $\begin{array}{l}\text { Planaltina-DF } \\
\text { (Midwest) }\end{array}$ & $\begin{array}{c}\text { Nova Porteirinha-MG } \\
\text { (Southeast) }\end{array}$ & $\begin{array}{c}\text { Pelotas-RS } \\
\text { (South) }\end{array}$ & $\begin{array}{c}\text { Mean } \\
\text { environment }\end{array}$ \\
\hline & $\hat{\mu}_{1}+\hat{g}+\hat{g} e$ & $\hat{\mu}_{2}+\hat{g}+\hat{g e}$ & $\hat{\mu}_{3}+\hat{g}+\hat{g} e$ & $\hat{\mu}_{\mathrm{j}}+\hat{\mathrm{g}}_{\mathrm{i}}+\hat{\mathrm{g}}_{\mathrm{m}}$ \\
\hline 1 & 1697.97 & 1656.50 & 1147.76 & 1500.74 \\
\hline 2 & 1300.68 & 1106.55 & 737.75 & 1048.32 \\
\hline 3 & 1854.39 & 1870.78 & 1520.43 & 1748.53 \\
\hline 4 & 1917.14 & 1985.50 & 1838.23 & 1913.63 \\
\hline 5 & 1684.14 & 1872.42 & 1550.16 & 1702.24 \\
\hline 6 & 1852.15 & 1743.82 & 1225.15 & 1607.04 \\
\hline 7 & 1740.98 & 1715.02 & 1516.40 & 1657.47 \\
\hline 8 & 1814.78 & 1852.74 & 1376.27 & 1681.27 \\
\hline 9 & 1635.28 & 1512.04 & 1497.11 & 1548.14 \\
\hline 10 & 1750.56 & 1840.18 & 1610.68 & 1733.81 \\
\hline 11 & 1895.07 & 1846.22 & 1698.87 & 1810.05 \\
\hline 12 & 1858.02 & 1743.79 & 1501.89 & 1701.24 \\
\hline 13 & 1216.42 & 1203.18 & 1257.27 & 1225.62 \\
\hline 14 & 1222.22 & 1056.17 & 1354.91 & 1211.10 \\
\hline 15 & 1267.03 & 1233.00 & 1111.18 & 1203.74 \\
\hline 16 & 1200.76 & 1218.55 & 1042.74 & 1154.02 \\
\hline 17 & 1222.66 & 1195.30 & 901.89 & 1106.62 \\
\hline 18 & 650.08 & 750.24 & 542.31 & 647.54 \\
\hline Overall mean & 1543.35 & 1521.78 & 1301.72 & 1455.62 \\
\hline Mean of best five progenies & 1875.35 & 1885.32 & 1643.67 & 1781.65 \\
\hline Genetic gain with the best progenies & $17.85 \%$ & $19.83 \%$ & $21.80 \%$ & $18.59 \%$ \\
\hline
\end{tabular}

Values in bold correspond to the five most productive progenies in each environment.

The progenies 4, 11, and 3 showed the best gain estimates with selection in all environments and medium environment (Table 2). Genetic gain obtained with selection of the best five genotypes in each environment (selection strategy 1) and mean environment (selection strategy 2 ) was higher than $17 \%$. These genotypic values can also be considered for recommendations of these progenies selected in other environments with G X E interaction standard similar to that found in this study. According to Maia et al. (2009), this is because the mixed model methodology penalizes predicted genotypic values. Thus, the same performance of genetic means $(\hat{\mu}+\hat{g})$ of the grain yield is expected when the above progenies are subjected to environments with features similar those of this study.

The best five progenies $(4,11,3,10$, and 5$)$ according to the genotypic value for the environment (selection strategy 2) were also the best according to selection strategy 3 , where adaptability (RPGV) and adaptability and stability (HMRPGV) are simultaneously capitalized (Table 3). According to Maia et al. (2009), capitalization of a G X E interaction depends on the selection of the progenies with greater adaptability and stability to the environments evaluated. In this context, these progenies must maintain the same level in environments with a standard G X E interaction similar to this study because they respond favorably to environmental influences and have high predictability to environmental changes. Maia et al. (2009), Neto et al. (2013), and Torres et al. (2016) verified the maintenance in ordering of cashew clones, rice, and cowpea genotypes, respectively, by strategies 1 and 2 used in this study, and they attributed such results to genotypic correlation across environments, which was positive and of similar magnitude to that observed in this study.

One of the main advantages of the adaptability and stability method employed in this study is to provide the results in the unity of assessed trait. Thus, it is possible to predict the gain with selection from values of HMRPGV $\mu$. Gain with the selection of the best progenies by strategy 3 was similar to that of other selection strategies. Therefore, based on the three 
Table 3. Estimates of harmonic mean of genetic values (HMGV), relative performance of genetic values (RPGV and RPGV $\mu$ ), and harmonic mean of the relative performance of predicted genetic values (HMRPGV and HMRPGV $\mu$ ) of 18 half-sib progenies of Jatropha predicted by BLUP (best linear unbiased prediction analysis) in three environments in Brazil.

\begin{tabular}{l|c|c|c|c|c}
\hline Progeny & HMGV & RPGV & RPGV $\mu$ & HMRPGV & HMRPGV $\mu$ \\
\hline 1 & 1453.57 & 1.02 & 1489.79 & 1.01 & 1474.41 \\
\hline 2 & 990.75 & 0.71 & 1036.72 & 0.69 & 1009.38 \\
\hline 3 & $\mathbf{1 7 3 2 . 6 0}$ & 1.20 & $\mathbf{1 7 4 6 . 2 0}$ & 1.20 & $\mathbf{1 7 4 5 . 4 4}$ \\
\hline 4 & $\mathbf{1 9 1 1 . 7 3}$ & 1.32 & $\mathbf{1 9 2 0 . 9 6}$ & 1.32 & $\mathbf{1 9 1 5 . 6 1}$ \\
\hline 5 & $\mathbf{1 6 9 2 . 1 1}$ & 1.17 & $\mathbf{1 7 0 4 . 2 8}$ & 1.17 & $\mathbf{1 6 9 9 . 9 1}$ \\
\hline 6 & 1554.73 & 1.10 & 1594.95 & 1.08 & 1577.36 \\
\hline 7 & 1651.13 & 1.14 & 1659.38 & 1.14 & 1658.99 \\
\hline 8 & 1650.74 & 1.15 & 1674.26 & 1.15 & 1668.25 \\
\hline 9 & 1545.73 & 1.07 & 1554.24 & 1.06 & 1548.68 \\
\hline 10 & $\mathbf{1 7 2 8 . 5 8}$ & 1.19 & $\mathbf{1 7 3 7 . 4 4}$ & 1.19 & $\mathbf{1 7 3 5 . 0 9}$ \\
\hline 11 & $\mathbf{1 8 0 6 . 2 4}$ & 1.25 & $\mathbf{1 8 1 4 . 4 8}$ & 1.25 & $\mathbf{1 8 1 2 . 4 3}$ \\
\hline 12 & 1687.76 & 1.17 & 1699.94 & 1.17 & 1699.13 \\
\hline 13 & 1225.19 & 0.85 & 1234.68 & 0.84 & 1223.58 \\
\hline 14 & 1198.53 & 0.84 & 1226.03 & 0.82 & 1191.72 \\
\hline 15 & 1199.89 & 0.83 & 1205.65 & 0.83 & 1205.06 \\
\hline 16 & 1148.34 & 0.79 & 1154.70 & 0.79 & 1154.48 \\
\hline 17 & 1085.67 & 0.76 & 1101.67 & 0.75 & 1097.54 \\
\hline 18 & 636.25 & 0.44 & 645.73 & 0.44 & 641.92 \\
\hline Overall mean & - & - & - & - & 1447.72 \\
\hline Mean of five best progenies & - & - & - & - & 1781.70 \\
\hline Genetic gain with the best progenies & & & & & $19.15 \%$ \\
\hline
\end{tabular}

Values in bold correspond to the best five progenies in each environment.

selection strategies used in this study, the progenies 4, 11, and 3 (selected in all environments, mean environment, and by adaptability and phenotypic stability methods) are the most suitable for cultivation in the three regions evaluated. Although the mixed model methodology does not require a specific number of environments for analysis of the G X E interaction, it is important that the evaluation of these genotypes in a greater number of environments in each region be conducted to provide further accurate results.

\section{Conflicts of interest}

The authors declare no conflict of interest.

\section{ACKNOWLEDGMENTS}

Research supported by Coordenação de Aperfeiçoamento de Pessoal de Nível Superior (CAPES), Fundação de Amparo à Pesquisa de Minas Gerais (FAPEMIG) and Conselho Nacional de Desenvolvimento Científico e Tecnológico (CNPq).

\section{REFERENCES}

Bahadur B, Sujatha M and Carels N (2013). Jatropha, challenges for a new energy crop. Volume 2: genetic improvement and biotechnology. Springer Verlag, New York.

Bastos IT, Barbosa MHP, Resende MDV, Peternelii LA, et al. (2007). Avaliação da interação genótipo x ambiente em cana-de-açúcar via modelos mistos. Pesq. Agropec. Trop. 37: 195-203.

Bhering LL, Barrera CF, Ortega D, Laviola BG, et al. (2013). Differential response of Jatropha genotypes to different selection methods indicates that combined selection is more suited than other methods for rapid improvement of the species. Ind. Crops Prod. 41: 260-265. http://dx.doi.org/10.1016/j.indcrop.2012.04.026

Genetics and Molecular Research 15 (3): gmr.15038824 
Brasileiro BP, Silva SA, Souza DR, Santos PA, et al. (2013). Genetic diversity and selection gain in the physic nut (Jatropha curcas). Genet. Mol. Res. 12: 2341-2350. http://dx.doi.org/10.4238/2013.January.4.12

Carbonell SAM, Chiorato AF, Resende MDV, Dias LAS, et al. (2007). Estabilidade de cultivares e linhagens de feijoeiro em diferentes ambientes no Estado de São Paulo. Bragantia 66: 193-201. http://dx.doi.org/10.1590/S0006$\underline{87052007000200003}$

Carels N, Sujatha M and Bahadur B (2013). Jatropha, challenges for a new energy crop. Volume 1: farming, economics and biofuel. Springer Verlag, New York.

Cruz CD, Carneiro PCS and Regazzi AJ (2012). Modelos biométricos aplicados ao melhoramento genético. 4th edn. Editora UFV, Viçosa.

Dias S, Misra RC, Mahapatra AK, Gantayat BP, et al. (2010). Genetic variability, character association and path analysis in Jatropha curcas. World Appl. Sci. J. 8: 1304-1308.

Dias LAS, Missio RF and Dias DCFS (2012). Antiquity, botany, origin and domestication of Jatropha curcas (Euphorbiaceae), a plant species with potential for biodiesel production. Genet. Mol. Res. 11: 2719-2728. http:// dx.doi.org/10.4238/2012.June.25.6

Everson CS, Mengistu MG and Gush MB (2013). A field assessment of the agronomic performance and water use of Jatropha curcas in South Africa. Biomass Bioenergy 59: 59-69. http://dx.doi.org/10.1016/j.biombioe.2012.03.013

Freitas RG, Missio RF, Matos FS, Resende MDV, et al. (2011). Genetic evaluation of Jatropha curcas: an important oilseed for biodiesel production. Genet. Mol. Res. 10: 1490-1498. http://dx.doi.org/10.4238/vol10-3gmr1146

Freitas RG, Dias LAS, Cardoso PMR, Evaristo AB, et al. (2016). Diversity and genetic parameter estimates for yield and its components in Jatropha curcas L. Genet. Mol. Res. 15: 1-10. http://dx.doi.org/10.4238/gmr.15017540

Laviola BG, Alves AA, Gurgel FL, Rosado TB, et al. (2012). Estimates of genetic parameters for physic nut traits based in the germplasm two years evaluation. Cienc. Rural 42: 429-435. http://dx.doi.org/10.1590/S0103-84782012000300008

Laviola BG, Silva SDA, Juhász ACP, Rocha RB, et al. (2014). Desempenho agronômico e ganho genético pela seleção de pinhão-manso em três regiões do Brasil. Pesq. Agropec. Bras. 49: 356-363. http://dx.doi.org/10.1590/S0100$\underline{204 X 2014000500005}$

Maia MCC, Resende MDV, Paiva JR, Cavalcanti JJV, et al. (2009). Seleção simultânea para produção, adaptabilidade e estabilidade genotípicas em clones de cajueiro, via modelos mistos. Pesq. Agropec. Trop. 39: 43-50.

Neto AR, Ramos EU, Junior., Gallo PB, Freitas JG, et al. (2013). Comportamento de genótipos de arroz de terras altas no estado de São Paulo. Rev. Cienc. Agron. 44: 512-519. http://dx.doi.org/10.1590/S1806-66902013000300013

Resende JCF, Londe LN and Neves WS (2013). Pinhão-manso. Epamig, Nova Poerteirinha.

Resende MDV (2007). SELEGEN-REML/BLUP: sistema estatístico e seleção genética computadorizada via modelos lineares mistos. Embrapa Florestas, Colombo.

Resende MDV, Prates DF, Yamada CK and Jesus A (1996). Estimação de componentes de variância e predição de valores genéticos pelo método da máxima verossimilhança restrita (REML) e melhor predição linear não viciada (BLUP) em pinus. Bol. Pesq. Flor. 32-33: 23-42.

Resende MDV and Duarte JB (2007). Precisão e controle de qualidade em experimentos de avaliação de cultivares. Pesq. Agropec. Trop. 37: 182-194.

Rosado AM, Rosado TB, Alves AA, Laviola BG, et al. (2012). Seleção simultânea de clones de eucalipto de acordo com produtividade, estabilidade e adaptabilidade. Pesq. Agropec. Bras. 47: 964-971. http://dx.doi.org/10.1590/S0100$\underline{204 X 2012000700013}$

Santos DN, Ferreira JL, Pasqual M, Generoso AL, et al. (2016). Population structure of jatropha and its implication for the breeding program. Genet. Mol. Res. 15: 1-10. http://dx.doi.org/10.4238/gmr.15017770

Teodoro PE, Costa RD, Rocha RB and Laviola BG (2016a). Contribuição de caracteres agronômicos para a produtividade de grãos em pinhão-manso. Bragantia 75: 51-56. http://dx.doi.org/10.1590/1678-4499.314

Teodoro PE, Costa RD, Rocha RB and Laviola BG (2016b). Número mínimo de medições para a avaliação acurada de características agronômicas de pinhão-manso. Pesq. Agropec. Bras. 51: 112-119. http://dx.doi.org/10.1590/S0100$\underline{204 X 2016000200003}$

Torres FE, Teodoro PE, Rodrigues EV, Santos A, et al. (2016). Simultaneous selection for cowpea (Vigna unguiculata L.) genotypes with adaptability and yield stability using mixed models. Genet. Mol. Res. 15: 1-11. http://dx.doi. org $/ 10.4238 / \mathrm{gmr} .15028272$

Wani TA, Kitchlu S and Ran G (2012). Genetic variability studies for morphological and qualitative attributes among Jatropha curcas L. accessions grown under subtropical conditions of North India. S. Afr. J. Bot. 79: 102-105. http:// dx.doi.org/10.1016/j.sajb.2011.10.009

Genetics and Molecular Research 15 (3): gmr.15038824 